\title{
Acidulated soybean oil in diets for rainbow trout alevins (Oncorhynchus mykiss) on its performance under commercial conditions
}

\author{
Aceite acidulado de soya en dietas para alevines de trucha arco iris (Oncorhynchus \\ mykiss) sobre su rendimiento bajo condiciones comerciales
}

\author{
M.A. Elguera ${ }^{1,3}$, V.J. Vergara ${ }^{1}$, J. F. Vega-Vilca ${ }^{2}$
}

\begin{abstract}
Objectives: To evaluate the inclusion of acidulated soybean oil in diets for rainbow trout alevins (Oncorhynchus mykiss) on its performance under commercial conditions. Methodology: Forty thousand and five hundred rainbow trout alevins were used and raised in ponds. Three levels of acidulated soybean oil included in the diet of 0.0, 2.5 and $5.0 \%$ were evaluated. The study was conducted for 60 days. The variables evaluated were weight gain, feed intake, feed conversion, length gain, survival, growth rate, protein efficiency retention and feed cost $/ \mathrm{kg}$ of weight. The data obtained were analyzed using the analysis of variance of a completely randomized design. Results: The levels of acidulated oil used in the diets for trout alevins had a similar effect on the evaluated variables $(\mathrm{P}>0.05)$. Conclusions: The acidulated soybean oil can partially or totally replace the crude soybean oil, up to $5.0 \%$ in diets for rainbow trout alevins.
\end{abstract}

Keywords: Soybean oil, alevins, trout, performance

\section{Resumen}

Objetivos: Evaluar la inclusión del aceite acidulado de soya en dietas para alevines de trucha arco iris (Oncorhynchus mykiss) sobre su rendimiento en condiciones comerciales. Metodología: Se utilizaron 40500 alevines de trucha arco iris criados en estanques. Se evaluaron tres niveles de aceite acidulado de soya incluido en la dieta de 0,$0 ; 2,5$ y 5,0 \%. El estudio se realizó durante 60 días. Las variables evaluadas fueron ganancia de peso, consumo de alimento, conversión alimenticia, incremento de longitud, sobrevivencia, tasa de crecimiento, retención de eficiencia proteica y costo de alimento $/ \mathrm{kg}$ de peso. Los datos obtenidos fueron analizados utilizando el análisis de varianza de un diseño completamente al azar. Resultados: Los niveles de aceite acidulado utilizados en las dietas para alevines de trucha tuvieron similar efecto en las variables evaluadas $(\mathrm{P}>0,05)$. Conclusiones: El aceite acidulado de soya puede reemplazar parcial o totalmente al aceite crudo de soya, hasta en un 5,0\% en dietas para alevines de trucha arco iris.

Palabras clave: Aceite de soya, alevines, trucha, rendimiento

\section{Introduction}

The fishing resource is a very important food source in the world. The production of this resource has been developing and increasing in recent years (FAO, 2001). In Peru, the development of aquaculture is mainly oriented to the production of rainbow trout (Oncorhynchus mykiss) with a production of 52 thousand tons per year, which represents approximately $52.16 \%$ of this activity (PRODUCE, 2016). Fish feed represents between 70 to 80 percent of production costs and energy in fish diets is an important component, so the inclusion of new energy ingredients should be taken into account (Castelló-Orvay, 2000). In the oil refining industry, by-products are generated that can be used in fish feed, such as acidulated oil. Acidulated oils are a product of the process of refining vegetable oil, they are a source of energy and essential fatty acids (Leeson \& Summers, 2005), the quantity and composition of these oils depends on the type and quality of the crude oil, as well as of the conditions of the refining process (Woerfel, 1983). The acidulated soybean oil has been used in broiler chickens (Bedoya, 2003; Pérez 2011) and fish such as tilapia and trout (Bazán, 2002; Aguilar et al., 2012; Herbas, 2017). In these studies, it has proven to be a good substitute for traditional input; in trout has not been evaluated in the stage of alevins in commercial conditions so the objective of the research is to evaluate the inclusion of acidulated soybean oil in rainbow trout alevins and its performance in commercial conditions.

${ }^{1}$ Facultad de Zootecnia, Universidad Nacional Agraria La Molina, Lima, Perú.

${ }^{2}$ Escuela Profesional de Ingeniería Zootécnica, Universidad Nacional José Faustino Sánchez Carrión, Lima, Perú.

Corresponding author: marioelguerav@gmail.com 


\section{Methodology}

The study was conducted at the Fish Production Center of SAIS "Túpac Amaru" Ltd. No. 1, Canchayllo district, Jauja province, Junín, at 3771 meter above sea level, latitude $11^{\circ} 48^{\prime} 7^{\prime \prime}$ South, longitude $75^{\circ} 43^{\prime} 3^{\prime \prime}$ West. Concrete ponds were used in parallel with an effective capacity of $2.25 \mathrm{~m} 3$ with an average flow of $1.25 \mathrm{l} / \mathrm{s}$. The average water temperature was $12^{\circ} \mathrm{C}$, with dissolved oxygen of 7.35 $\mathrm{mg} / \mathrm{l}$, meeting the water quality requirements for trout farming (de La Oliva, 2011). The evaluation was carried out in the months of March and April 2015 with a total duration of 60 days. Forty thousand and five hundred rainbow trout alevins were used, with an approximate live weight of $0.126 \mathrm{~g}$ and a length of $2.26 \mathrm{~cm}$. The fish were randomly distributed in 9 ponds, with 4500 fish per pond. The feeding of the fish was every day. The feeding was done six times a day $(8: 30,10: 00,11: 30,13: 00,14: 30$ and 16:00 hours) to satiety, with a manual distribution of feed. Every 15 days with samples representing $10 \%$ of each pond, the weight and length of the fish, feed consumption, daily weight gain, feed conversion, growth rate, survival, retention of protein efficiency and cost per kg of weight gained were determined. A digital scale (approx. $1 \mathrm{~g}$ ) and an ichthyometer (Ezkailu model, $25 \mathrm{~cm}$ ) were used to measure weight and length. The feed consumption was calculated considering the total biomass of fish per pond, starting with $8 \%$ of the biomass, then the remaining feed was weighted and by difference the amount of feed consumed was obtained. The daily weight gain was obtained by the difference between the final weight and the initial weight, divided by the evaluation time. Survival was determined as a percentage, relating the number of surviving fish at the end of the evaluation period with respect to the number of initial fish. Protein efficiency retention was calculated by increasing the wet weight divided on the crude protein (Pellet \& Young, 1980). The data obtained were analyzed using a variance analysis of a ompletely randomized design with three treatments and three replications for each treatment. Three experimental diets for rainbow trout alevins were formulated, according to NRC (2011). Table 1 shows the ingredients of the diets used. The results of the proximal analysis are shown in Table 2 . The treatments were $\mathrm{T}_{1}: 0.0 \%, \mathrm{~T}_{2}: 2.5 \%$ and $\mathrm{T}_{3}: 5.0 \%$ of acidulated soybean oil in the diet, crude soybean oil was replaced weight by weight for acidulated soybean oil.
Table 1

Formulation of diets for treatments

\begin{tabular}{lrcc}
\hline & \multicolumn{3}{c}{ Treatments $^{1}$} \\
\cline { 2 - 4 } Ingredient (\%) & $\mathrm{T}_{1}$ & $\mathrm{~T}_{2}$ & $\mathrm{~T}_{3}$ \\
\hline Prime fish meal, 66 & 30.00 & 30.00 & 30.00 \\
Wheat pollard & 23.64 & 23.64 & 23.64 \\
Soybean cake, 47 & 20.00 & 20.00 & 20.00 \\
Meat meal, 60 & 20.00 & 20.00 & 20.00 \\
Crude soybean oil & 5.00 & 2.50 & 0.00 \\
Acidulated soybean oil & 0,00 & 2.50 & 5.00 \\
Binder & 0.50 & 0.50 & 0.50 \\
Salt & 0.43 & 0.43 & 0.43 \\
Vitamin premix & 0.20 & 0.20 & 0.20 \\
Choline chloride & 0.10 & 0.10 & 0.10 \\
Additives & 0.10 & 0.10 & 0.10 \\
Antioxidant & 0.03 & 0.03 & 0.03 \\
\hline Total & 100.00 & 100.00 & 100.00 \\
\hline${ }^{1} \mathrm{~T}_{1}$, crude soybean oil (5.0 \%) and acidulated soybean oil $(0.0 \%) ;$ \\
$\mathrm{T}_{2}$, crude soybean oil (2.5\%) and acidulated soybean oil (2.5\%); \\
$\mathrm{T}_{3}$, crude soybean oil $(0.0 \%)$ and acidulated soybean oil $(5.0 \%)$. \\
\multicolumn{4}{c}{}
\end{tabular}

Table 2

Proximal analysis of experimental diets

\begin{tabular}{lrrr}
\hline \multirow{2}{*}{ Nutrient (\%) } & \multicolumn{3}{c}{ Treatments $^{1}$} \\
\cline { 2 - 4 } & \multicolumn{1}{c}{$\mathrm{T}_{1}$} & \multicolumn{1}{c}{$\mathrm{T}_{2}$} & \multicolumn{1}{c}{$\mathrm{T}_{3}$} \\
\hline Moisture & 8.57 & 8.26 & 8.16 \\
Crude protein & 43.13 & 43.35 & 43.69 \\
Ether extract & 10.19 & 10.33 & 10.20 \\
Crude fiber & 3.62 & 3.48 & 3.42 \\
Ash & 7.77 & 7.53 & 8.01 \\
Nitrogen-free extract & 26.72 & 27.05 & 26.51 \\
\hline Total & 100.00 & 100.00 & 100.00 \\
\hline${ }^{1} \mathrm{~T}_{1}$, crude soybean oil $(5.0 \%)$ and acidulated soybean oil $(0.0 \%) ;$ \\
$\mathrm{T}_{2}$, crude soybean oil $(2.5 \%)$ and acidulated soybean oil $(2.5 \%) ;$ \\
$\mathrm{T}_{3}$, crude soybean oil $(0.0 \%)$ and acidulated soybean oil $(5.0 \%)$.
\end{tabular}

\section{Results and discussion}

The variables evaluated between treatments were similar $(\mathrm{P}>0.05)$ under study conditions (Table 3$)$. Non-significant results were also obtained by some researchers using soybean-derived oils in fish feed (Aguilar et al., 2012; Herbas, 2017). Aguilar et al., (2012) obtained the same results by replacing $50 \%$ and $100 \%$ crude soybean oil with neutralized soybean fatty acids in diets for tilapia alevins, while Herbas (2017) replaced crude soybean oil weight by weight with acidulated soybean oil in trout alevins diets under laboratory conditions. With other types of oil, the response was similar. Bazán (2002) completely replaced a composed oil for acidulated 
fish oil in diets for trout of $38 \mathrm{~g}$ maintained for 120 days with controlled feeding, without finding significant differences. In studies in other parts of the world, where other oils and fats were used in trout and salmon, similar responses were also found (Mugrditchian et al., 1981).

Table 3

Effect of treatments on the performance of rainbow trout alevins

\begin{tabular}{|c|c|c|c|c|}
\hline \multirow{2}{*}{ Variable } & \multicolumn{3}{|c|}{ Treatments $^{1}$} & \multirow{2}{*}{$\mathrm{SEM}^{2}$} \\
\hline & $\mathrm{T}_{1}$ & $\mathrm{~T}_{2}$ & $\mathrm{~T}_{3}$ & \\
\hline Weight gain $(\mathrm{g})$ & 1.77 & 1.77 & 1.70 & 0.0301 \\
\hline Length gain $(\mathrm{cm})$ & 3.21 & 3.17 & 3.17 & 0.0497 \\
\hline Survival (\%) & 96.64 & 97.06 & 96.90 & 0.2922 \\
\hline Protein efficiency retention & 0.649 & 0.646 & 0.623 & 0.0106 \\
\hline Growth rate (g/day) & 0.029 & 0.029 & 0.028 & 0.0005 \\
\hline Feed intake $(\mathrm{kg})$ & 6.28 & 6.28 & 6.30 & 0.0180 \\
\hline Feed conversion & 0.82 & 0.82 & 0.85 & 0.0144 \\
\hline Feed cost $/ \mathrm{kg}$ of weight $(\$ / \mathrm{Kg})$ & 3.03 & 2.99 & 3.08 & 0.0532 \\
\hline
\end{tabular}

\section{Conclusions}

Under the conditions of the study, acidulated soybean oil in replacement of crude soybean oil up to $5.0 \%$ in starter diets for trout alevins, did not affect the weight, size, consumption of feed, feed conversion, growth rate, survival, retention of protein efficiency and the cost of feed per kilo of weight gained, suggesting that acidulated oil can be used in trout feeding. Evaluating acidulated soybean oil in diets in the stages of growth, finishing and reproduction in rainbow trout is a way to explore.

\section{Acknowledgments}

To Innovate Perú, for the financing of the research that was part of the Project "Improvement of the process of obtaining the byproducts of refining soybean oil for its use as an energy source in the rainbow trout feed" through Contract $\mathrm{N}^{\mathrm{o}} 169$ FINCyT-FIDECOM-PIPEI-2013.

\section{References}

Aguilar, J., Camacho, R., Celis, H., Chacón, L., Tupayachi, G. \& Vergara, V. (2012). Evaluación de ácidos grasos neutralizados en remplazo de aceite crudo de soya en dietas para alevines de tilapia. Reporte LINAPC, Universidad Nacional Agraria La Molina, Departamento de Nutrición, Lima, Perú.

Bazán, A. L. (2002). Utilización del aceite acidulado de pescado en remplazo del aceite compuesto para la alimentación de truchas arco iris. (tesis de maestria), Universidad Nacional Agraria La Molina, Lima, Perú.
Bedoya G. I. (2003). Determinación de la energía metabolizable del aceite acidulado de soya y su evaluación comparativa en dietas de inicio para pollos de carne (tesis de pregrado). Universidad Nacional Agraria La Molina, Lima, Perú.

Castelló-Orvay, F. (2001). Alimentos y estrategias de alimentación para reproductores y juveniles de peces marinos. En: R. Civera-Cerecedo, C. J. Pérez-Estrada, D. Ricque Marie y L. E. CruzSuárez (Eds.), Avances en Nutrición Acuícola IV. Memorias del IV Simposium Internacional de Nutrición Acuícola (pp. 550-569). Monterrey, México: Universidad Autónoma de Nuevo León.

de La Oliva, G. (2011). Manual de buenas prácticas de producción acuícola en el cultivo de trucha arco iris. Recuperado el 20 de febrero del 2019 de https://docplayer.es/6836930-Manual-debuenas-practicas-de-produccon-acuicola-en-elcultivo-de-trucha-arco-iris.html

FAO. (2001). Aquaculture development. 1. Good aquaculture feed manufacturing practice. Rome, Italy: FAO.

Herbas, S. G. (2017). Reemplazo del aceite crudo de soya por aceite acidulado de soya en dietas para alevines de trucha (tesis de pregrado) Universidad Nacional Agraria La Molina, Lima, Perú.

Mugrditchian, J., Hardy, R. \& Iowaka, W. (1981). Linseed oil and animal fat as alternative lipid sources in dry diets for chinook salmon (Oncorhynchus tshwytscha). Aquaculture, 25, 161-172. 
NRC. (2011). Nutrient requirements of fish and shrimp. Washington DC, US: The National Academies Press.

Pérez, J. (2011). Estimación de la energía metabolizable de dos aceites acidulados de sota y su efecto en la producción de pollas y gallinas Bovans White (tesis de maestría). Instituto de Enseñanza e Investigación en Ciencias Agrícolas, Montecillo, México.

PRODUCE. (2016). Anuario estadístico pesquero y acuícola. Recuperado 27 de febrero del 2019 de http://ogeiee.produce.gob.pe/index.php/shortco $\mathrm{d}$ e / o e e - d o c u m e n t o s publicaciones/publicaciones-anuales/item/775anuario-estadistico-pesquero-y-acuicola-2016
Siddiqui, T. Q. \& Khan, M. A. (2009). Effects of dietary protein levels on growth, feed utilization, protein retention efficiency and body composition of young Heteropneustes fossilis (Bloch). Fish Physiology and Biochemistry, 35, 479-488.

Woerfel, J. B. (1983). Alternatives for processing of Soapstock. Journal of the American Oil Chemists'Society, 60, 310-313. 